\title{
Industrial Stability and the President's Second Industrial Conference
}

\author{
By George W. Wickersham \\ Formerly Attorney-General of the United States
}

\section{A} CONFERENCE called by the President to consider questions affecting the relation of employers and employees in industry was held in Washington, October 6-23,. 1919. It was composed of three distinct groups, one representing labor, one representing capital, and the third representing the public. At the outset, it was arranged that each of these groups should vote as a unit upon all questions brought before the conference for determination. The conference was handicapped from beginning to end by the pendency of the strike of employees of the United States Steel Corporation.

\section{Collective Bargaining}

The principal question discussed was that of collective bargaining. After twenty-three meetings, the conference adjourned, not having been able to reach any conclusion. The group representing the public addressed a communication to the President, pointing out that the conference had not, at any time, rejected the principle of the right of the workers to organize and to bargain collectively with their employers; stating also that the difficulty which arose (the issue upon which the conference failed to agree) was not the principle involved, but the method of making it effective. They said:

We believe that the right of the workers to organize for the purpose of bargaining collectively with their employers through representatives of their own choosing cannot be denied or assailed. As representatives of the public we can interpret this right only in the sense that wage workers must be free to choose what organizations or associations, if any, they will join for this purpose.

They expressed their conviction of the necessity of setting up some machinery for effecting the speedy adjustment of disputes arising between workers and employers, whether the latter be private individuals or firms, or public and governmental authorities. They further expressed the opinion that a small committee selected by the President, composed of persons of varied interests and points of approach, should take up the matter, and prepare, along some such line as that indicated in their communication, a program which would be of present value.

In accordance with this suggestion, the President, during the following month (November) invited a group of seventeen men, selected without recognition of distinctive interests, to meet on December 1, for the purpose, as expressed in his letter of invitation, of having "concern that our industries may be conducted with such regard for justice and fair dealing that the workman will feel himself induced to put forth his best effort, that the employer will have an encouraging profit and that the public will not suffer at the hands of either class." The President expressed the hope "that this conference may lay the foundation for the development of standards and machinery within our industries by which these results may be attained." The conference was expressly relieved from the consideration of any then existing industrial dispute. 
The group selected for this conference was composed of the Secretary of Labor, the Honorable William B. Wilson, who was chosen chairman, Herbert Hoover, who was made vicechairman, three ex-governors of states, two former attorneys-general of the United States, a former secretary of Commerce and Labor, three college professors, two newspaper editors, an efficiency engineer, a railroad official, the head of a large mail order house in Chicago, the counsel of a large industrial corporation, and a retired lawyer and economist. ${ }^{1}$ Four of them were residents of the state of New York, four of Massachusetts, two of California, and one of each of the states of Pennsylvania, Ohio, Virginia, Illinois, Minnesota, Kansas and Texas.

\section{President's Annual Message}

Almost coincidently with the assembly of the conference in Washington, the President transmitted his annual message to the Congress, in which he dealt at some length with the subject of the relations between labor and capital. After pointing out the absolute need of a definite program to secure an improvement in the conditions of labor, the President urged the Congress to help in the difficult task of finding a method to bring about a general democratization of industry, based upon a full recognition of the right of those who work, in whatever rank, to participate in some organic way in every decision which directly affects their welfare.

1 The members of this conference were: William B. Wilson, Chairman, Herbert Hoover, Vice Chairman, Martin H. Glynn, Thomas W. Gregory, Richard Hooker, Stanley King, Samuel W. McCall, Henry M. Robinson, Julius Rosenwald, George T. Slade, Oscar S. Straus, Henry C. Stuart, William O. Thompson, Frank W. Taussig, Henry J. Waters, George W. Wickersham, Owen D. Young, Willard E. Hotchkiss, Henry R. Seager, Mr. Hotchkiss and $\mathbf{M r}$. Seager being Executive Secretaries.
It is with this purpose in mind, he said, that $I$ called a conference to meet in Washington on December 1 to consider these problems in all their broad aspects with the idea of bringing about a better understanding between these two interests.

It thus was made apparent to the conference that its main purpose was to seek the best means of promoting better relations between employers and employees in industry, as a condition to the establishment and maintenance of industrial peace and justice.

Warned by the experience of the previous conference, the new body was determined at least to map out its work in executive session. Proceeding in this manner, in about three weeks the conference was able unanimously to reach a practical result in the formulation of a preliminary statement to the public, which was issued on December 19,1919 , outlining the basis of the recommendations which the conference was disposed to make, and upon which criticism and suggestion were invited from any interested source.

After a recess over the Christmas holidays, the conference reconvened in Washington on January 12, and took up for consideration a very considerable body of comment and criticism upon its preliminary statement which, during the interval, had come from newspapers and other sources. Representatives of labor and capital also were called before the conference in executive session, who spoke for large numbers of employers and employees, giving the conference the benefit of very frank expressions of opinion and testimony concerning their experience. After consideration extending over a period of six weeks or more, the final report of the conference was submitted to the President on March 6, 1920.

\section{Report of the Conference}

The conference did not pretend to have found any sovereign remedy for all 
industrial ills. It recognized frankly that the causes of industrial unrest were many.

Among others they include the rise in the cost of living, unrestrained speculation, spectacular instances of excessive profits, excessive accumulation and misuse of wealth, inequality in readjustments of wage schedules, release of ideas and emotions by the war, social revolutionary theories imported from Europe, the belief that free speech is restricted, the intermittency of employment, fear of unemployment, excessive hours of work in certain industries, lack of adequate housing, unnecessarily high infant mortality in industrial centers, loss of personal contact in large industrial units and the culmination of a growing belief on the part of both employers and employees that a readjustment is necessary to a wholesome continuity of their united effort.

\section{Personal Relationship between Employer and EMployee}

The conference saw in the principle of collective bargaining but one element in a problem of many aspects. They recognized that there was fundamentally on the part of wage workers a deep-seated unrest and dissatisfaction with their condition and the share which they were receiving of the profits of industry.

Contradictory forces are at play with the situation. There is the pressure of the great federated labor organizations on the one hand; there are the great corporate organizations on the other. There are the cross-currents of particular organizations having for their purpose, not the betterment of conditions, so much as the establishment of a different social order from that existing. The atmosphere in which all of these work is that of a disorganized world of slackened industry, suspended commerce, constant labor disputes interrupted transportation and industry, phenomenally high wages and higher prices. The demands of the organizations of wage workers extend from shorter hours of labor, better conditions and higher wages, to the undisguised con- fiscation of existing property rights in the interest of employees, such as the so-called Plumb Plan for the acquisition and control of railroads, and the undisguised syndicalism and anarchy of the I. W. W. In the face of this seething mass of conflicting aims and action, the individual worker who is desirous of peaceful working conditions, of giving a fair day's labor for an honest wage, on the one hand, and the fair-minded employer, willing to meet those demands and to deal justly and honorably with his employees, on the other, seem to have little opportunity; yet, the hope of America lies in such as these. No progress towards permanent happiness can be made on the basis of perpetual industrial warfare or of spoliation of existing property rights; nor is there, except through the sane process of sober industry, any possibility of the attainment of stable national prosperity.

The conference asserts in its report that the foundation of industrial peace is to be found in the right relationship between employer and employee, and that such relation can be best promoted by the deliberate organization of that relationship. In other words, their view was that the immediate problem before them was not to encourage and promote the division of society into two or more armed camps, but rather to endeavor to minimize and, so far as possible, to remove class spirit, by drawing employer and employee into that personal relationship which would make manifest to each the essential humanity of the other; to demonstrate the oneness of humanity rather than to accentuate the separateness of contending human forces. The conference believed that this end could be promoted by starting with the plant or factory relationship, rather than by giving preference to a recognition of great industrial organizations. They 
recognized that with the growth in population, the development of economic industry and the necessity of vast bodies of workers to produce a standardized product upon which modern civilization so largely depends, it has become difficult, if not impossible, that the personal relation between employer and employee of the earlier and simpler days should be continued or restored. But the conference saw in the representative system, which lies at the basis of our own government, a means of providing the best substitute for the direct personal relation. Doubtless, the Saxon Wittenagemote and the New England town meeting furnished the ideal means of conducting self-government in the small communities of the early English and the American colonial days, but the great modern communities of our time cannot meet and debate in town council. They must select representatives, charged with the care of their interests, to deal for them with the problems of government, reporting to them for their ratification or disapproval from time to time those large and comparatively easily understood problems which control the course of our destiny and upon which the intelligent expression of popular will reasonably may be sought. So it is with industry: the right of the workers to deal with their employers through representatives of their own choosing, must be and largely is being accepted as unquestioned and indisputable.

The conference in their report emphasized the principle that "representatives must be selected by the employees with the utmost freedom." In order to prevent suspicion on either side, they recommended that selection be made by secret ballot. This applies to every form of collective reprèsentation. The conference said:
It is idle wholly to deny the existence of conflicting interests between employers and employees. But there are wide areas of activity in which their interests coincide. It is the part of statesmanship to organize identity of interest where it exists in order to reduce the area of conflict. The representative principle is needed to make effective the employee's interest in production, as well as in wages and working conditions. It is likewise needed to make more effective the employer's interest in the human element of industry.

Representative systems, embodying the practical application of this principle under the form of shop councils or shop committees, have been growing up recently in England and in America. More than two hundred of such organizations in the United States were brought to the attention of the conference. Excellent results appear to have been realized by that machinery. The large federations of labor have been disposed to view the growth of these organizations with unfriendly eyes, in the fear that they would constitute disintegrating forces, weakening the control of the nation-wide unions or federations. It may well be that men who are contented with their lot in a given industrial plant, where the workings of shop committees or other representative bodies of the employer and employee have provided effective machinery for removing grievances and averting strife, would be more unwilling than others to join in a strike or walkout in order to assist some other body of workers to compel compliance with their demands, or to aid the officials of some great labor organization to perpetuate or restore their power by bringing the combined forces of all the laborers in a given industry to bear upon employers, irrespective of the existence of any grievance upon the part of the employees in particular plants. But bearing in mind the primary needs of the community, to prevent interruption in production and to secure the continuance of steady em- 
ployment at fair wages, and to remove the great economic waste of industrial conflict, the conference saw in the formation and growth of the shop organizations a movement deserving of sympathetic interest and commendation, rather than of criticism.

\section{Development of Industrial STANDARDS}

The main duty imposed upon the conference by the President was to lay the foundation for the development of standards and of machinery within our industries, by which may be attained that condition described in his letter of appointment, in which the workman will feel himself induced to put forth his best effort, the employer will have an encouraging profit, and the public will not suffer at the hands of either. At first blush, viewed in the light of the actual existing conditions, this result would appear to be Utopian and unrealizable. To the conference, it seemed that the only avenue of approach to it lay through the encouragement of closer relations between employers and employees, and the creation of machinery adequate to deal promptly and fairly with all differences which may arise between themmachinery which should so establish itself in the confidence of both interests that neither would even consider resort to the crude and destructive methods of strikes and lockouts.

So far as the conference could learn, through the means of information at its disposal, the principal objection to the existing machinery of conciliation and arbitration in industry lies in the delays so generally experienced in reaching conclusions, and in the lack of confidence felt by the workers in the impartial fairness of arbitrators. A prompt decision, even though not ideal, is better than a more satisfactory but belated determination. A party to a controversy, even though he should fail to secure all that he desires in its determination, can adjust himself to a certainty, whatever it may be, when the period of uncertainty is ended, and go about his work under the determined conditions; whereas, prolonged uncertainty in result emphasizes discontent and leads to dissatisfaction with a decision finally reached which if made sooner might have been accepted with enthusiastic satisfaction. This fact, and the necessity of fair representation of each party upon any body created to determine disputes between employers and employed, were the controlling factors which led the conference to suggest the machinery proposed in its final report.

\section{Regional Division of Country}

The plan suggested in the report of the conference proposes to divide the United States into a number of regions, in each of which there is to be a permanent official known as the regional chairman, and conferences for inquiry and adjustment created to deal with industrial disputes. Panels are to be made up of men and women representative of employers and employees in given industries in each region, and whenever a dispute arises which cannot be settled by negotiation or by existing machinery, provision is made for the submission of the dispute to a regional adjustment conference, to be composed of two representatives of each of the parties to the dispute and two representatives to be selected by each side from the panels adopted for the region, the regional chairman to preside without a vote at the conference. If the conference reaches a unanimous agreement, it shall be regarded as a collective bargain between the parties to the dispute, and shall have the force and effect of a trade agreement. If the conference does 
not reach an agreement with respect to a dispute over wages, hours, or working conditions, it is to make a finding of the material facts and state the reasons why it is unable to reach an agreement.

An appeal lies from a finding of a regional adjustment conference, at the option of the parties, either (a) to an umpire agreed upon, or $(b)$ to a national industrial board of nine permanent members to be appointed by the President, sitting at the national capitol. Where the parties do not agree to submit to a regional adjustment conference, provision is made for the organization of a regional board of inquiry, to investigate any actual or pending dispute, and to make and publish a report of the issues, in order that the public may know the facts pertaining to the dispute. At any time pending such inquiry, by consent of the parties, the board may become an adjustment conference whose report shall constitute a binding agreement, as above stated. The conference felt that a clear impartial presentation of the facts concerning any industrial dispute would tend to the creation of public sentiment, which, when informed, is always controlling, in the long run, upon industrial controversies. The conference had to choose between the course adopted in the state of Kansas by the enactment of the Industrial Court Law, and a continuation of the principle of establishing and encouraging resort to machinery for the ascertainment and publication of facts upon which public opinion might be formed. The conference recognized the limitations of legal processes to compel men to labor against their will. Repression and coercion easily become convertible into oppression. While it is, of course, true that the law of criminal conspiracy can be reëxtended to reach and punish those who deliberately plan and compel the suspension of essential industry, no state of industrial peace and prosperity can be built upon the attempted coercive control of workers.

\section{Employees of Private Industry and Public Employees}

The conference drew a distinction in its report between employees in private industry and public employees. As to the latter, it said:

When men and women enter the public service they become a part of the machinery of government, and servants of the people. Continuous and effective service by these employees is not only essential, but constitutes the functioning of government. Even the right of the individual to retire is limited by his duty to give due notice, dependent upon the character of his service, so that there may be no cessation in its performance. Concerted retirement of any particular group from their post of duty may result in the paralysis of important public functions, and is nothing less than a blow at the government itself struck by those on whom rests the obligation of helping to conduct it.

On the other hand, the Conference recognized the right of workers to strike, the undesirability of attempting to coerce them to work against their will, and the great desire of bringing about such relations between employers and employed as to afford no justification for the exercise of that right, and the establishment of a basis of informing public opinion so as to bring to bear that great weapon upon all threatened interruption of industry.

The Kansas plan has proceeded on a different basis. It seeks to clothe with a public interest certain selected industries, namely, the production of food, the production of clothing, and the production of coal. It creates a tribunal for the determination of all disputes affecting those industries, and makes it a crime punishable with fine and imprisonment to interrupt or seek to interrupt their continued functioning. One of the great advantages of the American state federal system is 
that new methods of dealing with social questions may be tried out in one or more states under conditions which, if they be unsuccessful, will restrict the area of injury, whereas, if successful, their example may inspire other states to adopt like methods. The Kansas experiment is as yet too young to demonstrate whether or not it can successfully be carried out, even in a state whose industries are largely agricultural. The President's industrial conference was unanimously of the opinion that no such experiment should be attempted in the national field until a far more complete demonstration had been made than was yet furnished.

The report also dealt with many subjects, such as hours of labor, women in industry, child labor, housing, profit sharing and gain sharing, thrift agencies, inflation and high cost of living, public employees, agriculture, unemployment and part-time employment, and public employment clearing house.

It is impossible within the limits of this paper even to summarize what was discussed under those heads. Every one of those subjects figures in an important way in the causes of the present unrest. Perhaps more, certainly as much as any other of those causes, is the phenomenal and disproportionate growth of large fortunes, resulting in a widespread feeling among war workers that they have been unjustly exploited for the benefit of men whom they regard as no better, wiser or abler than themselves. They see, too often perhaps, unjust exactions in long hours of monotonous and unin. spiring labor, in order, as they view it, that undue profits may be realized by employers. Too seldom are the employees fairly shown the problems of the employer, and the great obstacles in the way of conducting an industry with reasonable profit to a body of stockholders whose collective contributions have created the industry. Only the establishment of fair, frank, direct and manly relations between employers and employed can remove the attitude of hostility and suspicion respecting the employer class which exists on the part of large bodies of wage workers in industry.

\section{Summary}

Whether or not Congress will adopt and put into effect the recommendations made by the Industrial Conference has not yet been determined. Doubtless, nothing can be expected until after the presidential election. Much other progress awaits upon the determination of that event. When the smoke of conflict clears away and men cease to be afraid to give full expression to their beliefs and convictions because of their possible political effect, a calm consideration of the problem, with a view to the-best public interests, doubtless will produce some governmental machinery along the lines suggested, or along some other lines intended to provide a practical method for the speedy determination of controversies in industry, and the ending of the present anomalous state of international relations, the recognition of the interdependence of all nations, and a common responsibility for the restoration of normal conditions in the world, may induce a better spirit of mutual helpfulness, of recognition of common interests between those who employ and those who work for a daily wage, out of which there may come, not a greater impetus towards the establishment of a different social order, but a more just and temperate employment of the machinery of our own government towards the attainment of the ideals of American life, which have guided us through a century and a half of progress to a position of unprecedented national prosperity. 